MINI-REVIEW

\title{
Significance of the Y-box proteins in human cancers
}

\author{
Ken Matsumoto $^{1}$ and Boon-Huat Bay ${ }^{2 *}$ \\ ${ }^{1}$ Laboratory of Cellular Biochemistry, RIKEN (The Institute of Physical and Chemical Research), 2-1 Hirosawa, Wako, \\ Saitama 351-0198, Japan. ${ }^{2}$ Department of Anatomy, Faculty of Medicine, National University of Singapore, 4 Medical \\ Drive, Blk MD 10, S 117 597, Singapore \\ *Correspondence to: Boon-Huat Bay, Email: antbaybh@nus.edu.sg, Tel: +65 6874 6139, Fax: +65 67787643
}

Journal of Molecular and Genetic Medicine (2005), 1(1), 11-17

(C) Copyright Matsumoto and Bay

(Received 24 June 2005; Revised 01 August 2005; Accepted 01 August 2005; Available online 03 August 2005; Published 19 August 2005)

\begin{abstract}
Y-box proteins belong to the cold shock domain family of proteins that are known to be involved in both transcriptional and translational control. Here, we give a brief overview of the structure, regulation and physiological functions of the Y-box proteins. This is followed by examining the role of Y-box protein 1 (YB-1), the most extensively studied of the Y-box protein in tumorigenesis, and its clinicopathological significance. YB-1 has the potential to be a prognostic marker and predictor of chemoresistance in human cancers.
\end{abstract}

KEYWORDS: YB-1, structure and regulation, tumorigenesis, clinicopathological significance, prognostication, chemoresistance

\section{INTRODUCTION}

Deregulation of proper transcriptional and translational control triggers tumorigenesis. Several multifunctional proteins are involved in both transcriptional and translational control (Wilkinson and Shyu, 2001). Here we focus on a family of such multifunctional proteins, the Ybox protein family, in terms of its significance in cell proliferation and cancer. As different aspects of the Ybox proteins have already been reviewed (Matsumoto and Wolffe, 1998; Swamynathan et al, 1998; Evdokimova and Ovchinnikov, 1999; Kohno et al, 2003), we briefly appraise the structure and functions of the Y-box proteins with the emphasis on recent findings. We then summarize the role of a Y-box protein YB-1 in cancer and its use in the clinical setting.

Y-box proteins (or Y-box binding proteins) are so named because they were originally identified as DNA binding proteins that are capable of associating with the Y-box (inverted CCAAT-box) sequence of the major histocompatibility complex class II gene. Y-box proteins have thus far been known to regulate positively or negatively a number of genes, such as multidrug resistance 1 , cyclin
A, cyclin B1, matrix metalloproteinase 2 and collagen alpha2(I) (Higashi et al, 2003a; Jurchott et al, 2003; Kohno et al, 2003). However, members of Y-box protein family are also found in the cytoplasm and associated with mRNAs as major components of messenger ribonucleoprotein particles. Y-box proteins regulate translation in a dose-dependent manner; low concentrations of $\mathrm{Y}$ box proteins activate translation and high concentrations repress it (Evdokimova and Ovchinnikov, 1999). Collectively, Y-box proteins have been implicated in the regulation of mRNA metabolism in multiple steps in both the nucleus and the cytoplasm, including transcription, splicing, mRNA stability and translation.

Structure and cellular localization of Y-box proteins Y-box proteins consist of three domains: the N-terminal domain, the cold shock domain (CSD) and the Cterminal tail domain (Figure 1). The CSD is a highly conserved nucleic acid binding domain that confers RNA- and single-stranded and double-stranded DNA binding activities to the Y-box proteins. Both the short $\mathrm{N}$-terminal and the C-terminal tail domains are less conserved among the Y-box proteins. The charged Cterminal tail domain of vertebrate $\mathrm{Y}$-box proteins, con- 
sisting of alternating clusters of acidic/aromatic and basic Y-box proteins have been shown to interact with a numamino acids, is likely to account for its RNA-binding ber of cellular and viral proteins that are involved in activity and ability for associating with various proteins. various cellular processes (Figure 2).

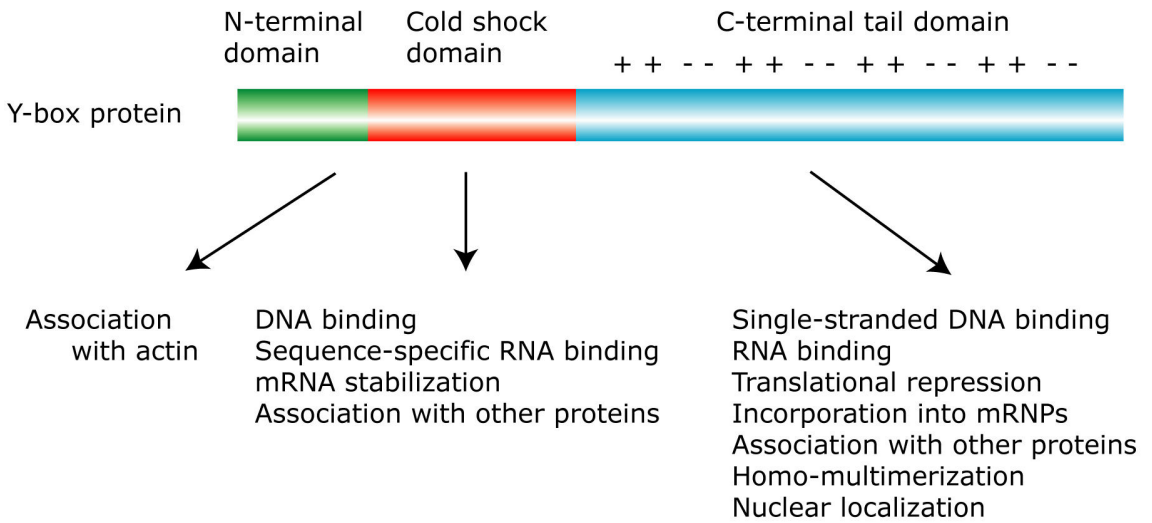

Figure 1. Schematic diagram depicting the structure of the Y-box protein. ++ and -- indicate clusters of basic and acidic/aromatic amino acids. Functions attributed to each domain are summarized at the bottom.

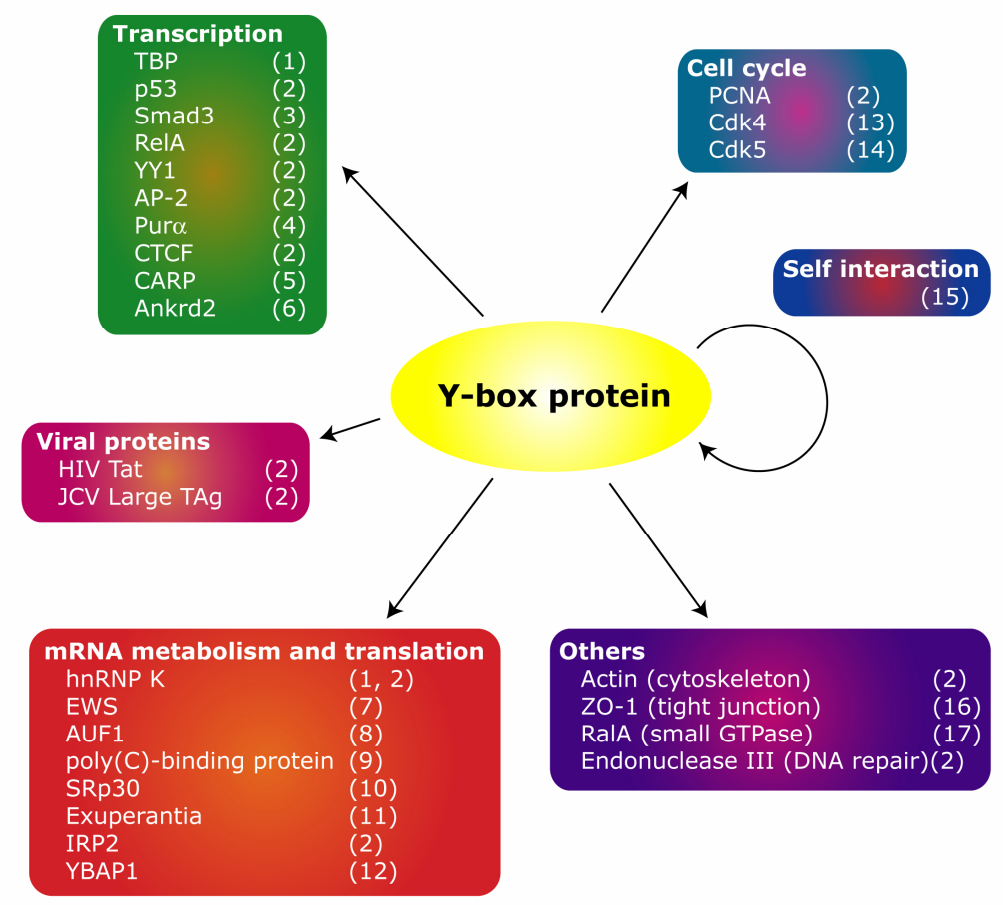

Figure 2. Cellular and viral proteins that interact with the Y-box protein. Numbers in parentheses indicate the references as follows: (1) Shnyreva et al, 2000, (2) Kohno et al, 2003; Swamynathan et al, 1998 and references therein, (3) Higashi et al, 2003b, (4) Safak et al, 1999, (5) Zou et al, 1997, (6) Kojic et al, 2004, (7) Chansky et al, 2001, (8) Moraes et al, 2003, (9) Funke et al, 1996, (10) Raffetseder et al, 2003, (11) Wilhelm et al, 2000, (12) Matsumoto et al, 2005, (13) Balda et al, 2003, (14) Moorthamer et al, 1999, (15) Matsumoto and Wolffe, 1998; Evdokimova and Ovchinnikov, 1999 and references therein, (16) Balda and Matter, 2000, (17) Frankel et al, 2005. 
In a variety of cell types, Y-box proteins are predominantly found in the cytoplasm. However, given that Y-box proteins regulate transcription, they are expected to localize to the nucleus. Y-box proteins are translocated into the nucleus by a number of conditions and mechanisms, including UV irradiation, hyperthermia, interferon-gamma treatment, adenovirus infection, interaction with p53 and a splicing factor SRp30c and high levels of ectopic YBlexpression (Higashi et al, 2003a; Kohno 2003; Raffetseder et al, 2003 and references therein; Zhang et al, 2003). Both the CSD and the tail domains are implicated in nuclear localization of YB-1; the tail domain seems to contain a non-canonical nuclear localization signal and the isolated CSD also contributes to nuclear retention (Bader and Vogt, 2005). Y-box proteins are capable of nucleocytoplasmic shuttling, which allows them to contribute to the coupling control of transcription and translation. Y-box proteins become associated with nascent transcripts cotranscriptionally and are presumed to accompany mRNA into the cytoplasm (Soop et al, 2003). Interestingly, a mouse Y-box protein MSY2 preferentially associates with mRNAs that are transcribed from genes containing Y-box sequences in their promoter regions and stores those mRNAs in male germ cells (Yang et al, 2005a).

\section{Regulation of the synthesis of Y-box proteins}

Experiments with overexpression or down-regulation of the Y-box proteins in cultured cells or animals have shown that the amount of Y-box proteins must be precisely controlled (see below). Therefore, it is important to understand how the synthesis of Y-box proteins is regulated. Recent data have shown that the synthesis of a Y-box protein, YB-1 (Y-box binding protein-1), is regulated both at transcriptional and post-transcriptional levels. YB-1 mRNA accumulates when cells are treated with cisplatin or UV irradiation (Ohga et al, 1996). Transcription of the YB-1 gene is stimulated by p73 through an enhanced recruitment of the c-Myc-Max complexes to E-box sequences in the YB-1 promoter (Uramoto et al, 2002). Once synthesized, YB-1 mRNA is negatively regulated by its own product. YB-1 protein represses translation of YB1 mRNA by binding to specific elements in the 5'- and 3'untranslated regions (Fukuda et al, 2004; Skabkina et al, 2005). This self-regulation may contribute towards maintaining the concentration of YB-1 protein optimal in a cell.

\section{Physiological functions of Y-box proteins}

In human and mouse, there are three Y-box proteins, two of which are expressed in both somatic cells and germ cells (Table 1). The most extensively studied Y-box protein, YB-1, is ubiquitously expressed in various tissues. Human Contrin and mouse MSY2 are germ cell-specific members of the Y-box protein family. Analyses of the effects of targeting Y-box genes in chicken cells and mice have been widely carried out in the last three years. Chicken B-cell lymphoma DT40 cells are widely used to study functional consequences of disrupting specific genes because of the high frequency of homologous recombination. The YB-1 (or YB-1b) gene in DT40 cells has been disrupted by two independent groups of investigators; one group reported that $\mathrm{YB}-1^{+/-}$cells show slow-growth phenotype and increased DNA content (Swamynathan et al, 2002). The other group of researchers found that heterozy- gous disruption resulted in no growth defects but homozygous gene disruptants exhibited a slow and cold-sensitive growth phenotype (Matsumoto et al, 2005). One research group tried to disrupt YB-1 gene in mice but encountered difficulties in disrupting both alleles of the YB-1 gene (Shibahara et al, 2004). They found hypersensitivity of the $\mathrm{YB}-1^{+/-}$cells to genotoxic stresses. However, as was the case in chicken cells, another group recently reported homozygous YB-1gene disruption, showing the importance of YB-1 in late stages of embryonic development (Lu et al, 2005). They observed developmental defects of YB- $1^{-/-}$ embryos after embryonic day 13.5 including craniofacial lesions, hemorrhage and respiratory failure, with $\mathrm{YB}-1^{-/-}$ MEF cells showing premature senescence and hypersensitivity to different cellular stresses. The reason for the presence or absence of the haplo-insufficient phenotypes is currently unknown. In mice lacking MSY2, both male and female homozygotes are sterile, a consequence of disturbed spermatogenesis due to reduction of postmeiotic germ-cell mRNAs in male and oocyte loss in female (Yang et al, 2005b). Overall, studies designed to reduce or deplete a Y-box protein in cells or whole organisms underscore the significance of Y-box proteins in appropriate cell growth, stress responses and development.

Table 1. Y-box proteins in human and mouse

\begin{tabular}{|l|l|l|l|}
\hline Human & Mouse & Expression & $\begin{array}{l}\text { Phenotype in } \\
\text { knockout mice }\end{array}$ \\
\hline \hline YB-1/DbpB & YB-1/MSY1 & Ubiquitous & $\begin{array}{l}\text { Embryonic/perinatal } \\
\text { lethality (neurologi- } \\
\text { cal abnormalities, } \\
\text { haemorrhage, respi- } \\
\text { ratory failure and } \\
\text { growth retardation)* }\end{array}$ \\
\hline DbpA & MSY4 & $\begin{array}{l}\text { Ubiquitous } \\
\text { (abundant in } \\
\text { heart, mus- } \\
\text { cle and } \\
\text { testis) }\end{array}$ & Unknown \\
\hline Contrin & MSY2 & Germ cells & $\begin{array}{l}\text { Male and female } \\
\text { infertility** }\end{array}$ \\
\hline
\end{tabular}

$*$ Lu et al, 2005

**Yang et al, 2005b

\section{Role of YB-1 in tumorigenesis}

The role of YB-1 in cancer progression has attracted attention in recent years.YB-1 has been found to be upregulated during prostate cancer tumor progression (GimenezBonafe et al, 2004). Increased YB-1 expression has been correlated with DNA topoisomerase II $\alpha$ and proliferating cell nuclear antigen expression in human lung cancer $(\mathrm{Gu}$ et al, 2001) and colorectal cancer (Shibao et al, 1999) and linked to markers of cellular proliferation in osteosarcoma (Oda et al, 1998). YB-1 has been identified as a cell cycle stage-specific transcription factor (Jurchott et al, 2003). Nuclear accumulation of YB-1 in HeLa cells was demonstrated to transcriptionally activate cyclin A and B1 genes, which are crucial for cell cycle progression. Increase in cyclin A has been reported to be associated with poor clinical outcome in breast cancer (Michalides et al, 2002).

In addition, YB-1 is believed to promote metastasis by enhancing the transcription of gelatinase $\mathrm{A}$, a matrix met- 
alloproteinase that facilitates cell migration (Cheng et al, 2002). Recently, Berquin et al. (2005) has also shown that YB-1 may induce epidermal growth factor (EGF) independence in mammary epithelial cells via activation of the EGF receptor pathway, thereby contributing to breast tumor aggressiveness. In yet another recent paper, Bergmann and colleagues (2005), using a transgenic mouse model, showed that overexpression of YB-1 may cause breast cancer through the induction of genetic instability.

On the other hand, YB-1 may have anti-oncogenic activity as it is reported to be capable of blocking oncogenic cell transformation (Bader and Vogt, 2005). The phosphoinositide 3-kinase (PI 3-kinase) pathway is known to show gain of function in human cancers (Bader and Vogt 2004). The catalytic subunits of PI 3-Kinase, p110 (of which $\mathrm{P} 3 \mathrm{~K}$ is a homolog) and Akt are oncoproteins and YB-1 is specifically known to inhibit P3K and Aktinduced transformation involving protein synthesis (Bader et al., 2003). YB-1 may interefere with the synthesis of growth-related proteins including growth factors, receptors, kinases, transcriptional regulators and cell cycle proteins associated with $\mathrm{P} 3 \mathrm{~K}$ and Akt pathways (Zimmer et al, 2000; Bader and Vogt 2004).

A seminal paper describing YB-1 expression in cancer tissues was first reported by Royer's group in breast cancer (Bargou et al, 1997). The pathological significance of YB-1 in a variety of cancers is shown in Table 2.

Table 2. Overexpression of YB-1 and pathological significance in human cancers

\begin{tabular}{|c|c|c|c|}
\hline Organ & Tumors & Pathological Significance & Reference \\
\hline \multirow[t]{3}{*}{ Breast } & Invasive ductal breast cancer & $\begin{array}{l}\text { Tumor aggressiveness and axillary lymph node } \\
\text { positivity }\end{array}$ & Huang et al, 2005 \\
\hline & & $\begin{array}{l}\text { Associated with progesterone receptor positivity } \\
\text { but no prognostic value }\end{array}$ & Saji et al, 2003 \\
\hline & $\begin{array}{l}\text { Breast cancer (histologic subtype not speci- } \\
\text { fied) }\end{array}$ & $\begin{array}{l}\text { Higher risk for relapse without postoperative } \\
\text { chemotherapy }\end{array}$ & Janz et al, 2002 \\
\hline \multirow[t]{3}{*}{ Ovary } & $\begin{array}{l}\text { Surface epithelial neoplasms (serous, muci- } \\
\text { nous, endometroid \& clear cell) }\end{array}$ & $\begin{array}{l}\text { Co-expression with P-glycoprotein associated } \\
\text { with poor survival }\end{array}$ & Huang et al, 2004 \\
\hline & Surface epithelial neoplasms (mainly serous) & $\begin{array}{l}\text { Higher nuclear expression in recurrent lesions } \\
\text { than in primary tumors }\end{array}$ & Yahata et al, 2002 \\
\hline & Serous adenocarcinoma & Poor prognosis & Kamura et al, 1999 \\
\hline \multirow[t]{4}{*}{ Lung } & Nonsmall cell lung cancer & $\begin{array}{l}\text { Nuclear expression correlated with reduced sur- } \\
\text { vival }\end{array}$ & Gessner et al, 2004 \\
\hline & & $\begin{array}{l}\text { Nuclear expression correlated with node metas- } \\
\text { tasis, stage of the disease and poor prognosis }\end{array}$ & Shibahara et al, 2001 \\
\hline & Squamous cell carcinoma & Poor prognosis & Shibahara et al, 2001 \\
\hline & Adenocarcinoma & Associated with T3-4 and Stage II-IV tumors & Gu et al, 2001 \\
\hline Thyroid & $\begin{array}{l}\text { Anaplastic (undifferentiated) carcinomas, } \\
\text { papillary carcinomas and follicular carcinomas }\end{array}$ & $\begin{array}{l}\text { High expression in anaplastic carcinoma (known } \\
\text { to be rapidly progressive) }\end{array}$ & Ito et al, 2003 \\
\hline Soft tissues & Synovial sarcoma & Poor prognosis & Oda et al, 2003 \\
\hline Large intestine & Colorectal adenocarcinoma & Proliferation associated marker & Shibao et al, 1999 \\
\hline
\end{tabular}




\section{YB-1 and chemoresistance in human tumors}

Substantial YB-1 expression was demonstrated in multidrug-resistant breast, gastric and pancreatic cell lines (Holm et al, 2004). Altered drug sensitivity to cisplatin, a very potent and widely used anti-cancer agent and mitomycin $\mathrm{C}$ has been observed following treatment of cells with antisense YB-1 (Ohga et al, 1996; Torigoe et al, 2005). Expression of YB- 1 protein has been reported to reflect the chemosensitivity of ovarian serous adenocarcinoma (Kamura et al, 1999) and breast cancer (Janz et al, 2002; Huang et al, 2005). Increased nuclear localization of YB-1 has been observed in acquired cisplatin-resistant ovarian cancer (Yahata et al, 2002).

YB-1 expression has also been shown to be associated with P-glycoprotein (Pgp) expression in breast cancer cells resulting in drug resistance (Bargou et al, 1997; Saji et al, 2003; Huang et al, 2005). Pgp, encoded by the MDR1 gene, is a member of the ATP-binding cassette transporter superfamily of proteins involved in the protection of cells from xenobiotics and drugs (Kuwano et al, 2003). Pgp has become an important molecular target for limiting chemoresistance as it plays a major role in the development of multidrug-resistant tumor type and is known to mediate resistance to a wide range of anticancer agents (Kuwano et al, 1999). Bay and co-workers have recently demonstrated a direct interaction between YB-1 and Pgp using the computer-based Resonance Recognition Model (Huang et al, 2005). The same investigators observed the occurrence of raised recurrence rates in breast tumor patients with high YB-1 expression who underwent a chemotherapy regime which contained anthracycline (a Pgp substrate). Besides breast cancer, YB-1 has been correlated with Pgp in ovarian cancer (Huang et al, 2004), prostate cancer (GimenezBonafe et al, 2004) and osteosarcoma (Oda et al, 1998).

YB-1 has been shown to bind p53 (Okamoto et al, 2000) and interaction with p53 could be necessary for the selfdefense of cells exposed to DNA-damaging agents $\mathrm{Ku}-$ wano et al, 2003). As mentioned earlier, p73, a close relative of the p53 family, has also been observed to stimulate transcription of the YB-1 promoter by enhancing the recruitment of the cMyc-Max complex to its target gene (Uramoto et al, 2002). c-Myc, an oncogene with a dual function in cell proliferation and apoptosis can confer resistance to cisplatin. p73 is known to induce apoptosis (Irwin et al, 2000). and p73 overexpressing clones have been observed to be cisplatin resistant (Gong et al, 1999). Hence, c-Myc and p73 may form a complex necessary in YB-1 mediated drug resistance (Uramoto et al, 2002).

\section{CONCLUSIONS}

Expression of the YB-1 protein has a prognostic significance in determining disease progression in human cancers. Perhaps more importantly, YB-1 has the potential to be a biological marker which predicts chemotherapy resistance and aid in the selection of appropriate adjuvant chemotherapy. There has been cumulative evidence in the literature to suggest that YB-1 is involved in pleiotropic resistance to different classes of DNA-targeting drugs (Levenson et al, 2000). As clinical drug resistance hampers effective chemotherapy, a recent focus in cancer therapeutic strategy is to develop molecular cancer therapeutics (Kuwano et al, 2003; Holm et al, 2004). In this regard, YB-1 holds promise as target molecule for the development of novel approaches in overcoming multidrug resistance in cancer chemotherapy (Janz et al, 2002).

\section{ACKNOWLEDGEMENTS}

We thank the Singapore National Medical Research Council (grants to BHB) and the Ministry of Education, Culture, Sports, Science, and Technology of Japan (to KM) for funding our work. We are grateful to Ms Song-Lin Bay for technical assistance.

\section{STATEMENT OF COMPETING INTERESTS}

The authors declared no competing interests.

\section{LIST OF ABBREVIATIONS}

CSD: Cold shock domain

YB-1: Y-Box binding protein-1

EGF: Epidermal growth factor

PI-3: Phosphoinositide 3-kinase

Pgp: P-glycoprotein

\section{REFERENCES}

Bader AG and Vogt PK. 2004. An essential role for protein synthesis in oncogenic cellular transformation. Oncogene, 23, 3145-3150.

Bader AG and Vogt PK. 2005. Inhibition of protein synthesis by $\mathrm{Y}$ box-binding protein 1 blocks oncogenic cell transformation. Mol Cell Biol, 25, 2095-2106.

Bader AG, Felts KA, Jiang N, Chang HW and Vogt PK. 2003. $\mathrm{Y}$ box-binding protein 1 induces resistance to oncogenic transformation by the phosphatidylinositol 3-kinase pathway. Proc Natl Acad Sci USA, 100, 12384-12389.

Balda MS and Matter K. 2000. The tight junction protein ZO-1 and an interacting transcription factor regulate ErbB-2 expression. EMBO J, 19, 2024-2033.

Balda MS, Garrett MD and Matter K. 2003. The ZO-1associated Y-box factor ZONAB regulates epithelial cell proliferation and cell density. J Cell Biol, 160, 423-432.

Bargou RC, Jurchott K, Wagener C et al. 1997. Nuclear localization and increased levels of transcription factor YB-1 in primary human breast cancers are associated with intrinsic MDR1 gene expression. Nat Med, 3, 447-450

Bergmann S, Royer-Pokora B, Fietze E et al. 2005. YB-1 provokes breast cancer through the induction of chromosomal instability that emerges from mitotic failure and centrosome amplification.Cancer Res, 65, 4078-4087.

Berquin IM, Pang B, Dziubinski ML, Scott LM et al. 2005. Ybox-binding protein 1 confers EGF independence to human mammary epithelial cells. Oncogene, 24, 3177-3186.

Chansky HA, Hu M, Hickstein DD and Yang L. 2001. Oncogenic TLS/ERG and EWS/Fli-1 fusion proteins inhibit RNA splicing mediated by YB-1 protein. Cancer Res, 61, 35863590 .

Cheng S, Alfonso-Jaume MA, Mertens PR and Lovett DH. 2002. Tumor metastasis suppressor nm23-beta inhibits gelatinase A transcription by interference with transactivator Y-box protein-1. Biochem J, 366, 807-816.

Evdokimova VM and Ovchinnikov LP. 1999. Translational regulation by Y-box transcription factor: involvement of the major mRNA-associated protein, p50. Int $\mathrm{J}$ Biochem Cell Biol, 31, 139-149. 
Frankel P, Aronheim A, Kavanagh E et al. 2005. RalA interacts with ZONAB in a cell density-dependent manner and regulates its transcriptional activity. EMBO J, 24, 54-62.

Fukuda T, Ashizuka M, Nakamura T et al. 2004. Characterization of the 5'-untranslated region of YB-1 mRNA and autoregulation of translation by YB-1 protein. Nucleic Acids Res, 32, 611-622.

Funke B, Zuleger B, Benavente R et al. 1996. The mouse poly $(\mathrm{C})$-binding protein exists in multiple isoforms and interacts with several RNA-binding proteins. Nucleic Acids Res, 24, 3821-3828.

Gessner C, Woischwill C, Schumacher A et al. 2004. Nuclear YB-1 expression as a negative prognostic marker in nonsmall cell lung cancer. Eur Respir J, 23, 14-19.

Gimenez-Bonfe P, Fedoruk MN, Whitmore TG et al. 2004. YB-1 is upregulated during prostate cancer tumor progression and increases P-glycoprotein activity. Prostate, 59, 337-349.

Gong JG, Costanzo A, Yang HQ et al. 1999. The tyrosine kinase c-Abl regulates $\mathrm{p} 73$ in apoptotic response to cisplatininduced DNA damage. Nature 399, 806-809.

Gu C, Oyama T, Osaki T, Kohno K. and Yasumoto K. 2001. Expression of $\mathrm{Y}$ box-binding protein-1 correlates with DNA topoisomerase II alpha and proliferating cell nuclear antigen expression in lung cancer. Anticancer Res, 21, 2357-2362.

Higashi K, Inagaki Y, Suzuki N et al. 2003a. Y-box-binding protein YB-1 mediates transcriptional repression of human alpha 2(I) collagen gene expression by interferon-gamma. J Biol Chem, 278, 5156-5162.

Higashi K, Inagaki Y, Fujimori K et al. 2003b. Interferongamma interferes with transforming growth factor-beta signaling through direct interaction of YB-1 with Smad3. J Biol Chem, 278, 43470-43479.

Holm PS, Lage H, Bergmann S et al. 2004. Multidrug-resistant cancer cells facilitate E1-independent adenoviral replication: impact for cancer gene therapy. Cancer Res, 64, 322-328.

Huang X, Ushijima K, Komai K et al. 2004. Co-expression of $\mathrm{Y}$ box-binding protein-1 and $\mathrm{P}$-glycoprotein as a prognostic marker for survival in epithelial ovarian cancer. Gynecol Oncol, 93, 287-291.

Huang J, Tan PH, Li KB, Matsumoto K, Tsujimoto M and Bay BH. 2005. Y-box binding protein, YB-1, as a marker of tumor aggressiveness and response to adjuvant chemotherapy in breast cancer. Int J Oncol, 26, 607-613.

Irwin M, Marin MC, Phillips AC. 2000. Role for the p53 homologue p73 in E2F-1-induced apoptosis. Nature, 407, 645-648.

Ito Y, Yoshida H, Shibahara K et al. 2003. Y-box binding protein expression in thyroid neoplasms: its linkage with anaplastic transformation. Pathol Int, 53, 429-433.

Janz M, Harbeck N, Dettmar P et al. 2002. Y-box factor YB-1 predicts drug resistance and patient outcome in breast cancer independent of clinically relevant tumor biologic factors HER2, uPA and PAI-1. Int J Cancer, 97, 278-282.

Jurchott K, Bergmann S, Stein U et al. 2003. YB-1 as a cell cycle-regulated transcription factor facilitating cyclin A and cyclin B1 gene expression. J Biol Chem, 278, 27988-27996.

Kamura T, Yahata H, Amada S et al. 1999.. Is nuclear expression of $\mathrm{Y}$ box-binding protein-1 a new prognostic factor in ovarian serous adenocarcinoma? Cancer, 85, 2450-2454.

Kohno K, Izumi H, Uchiumi T, Ashizuka M and Kuwano M. 2003. The pleiotropic functions of the Y-box-binding protein, YB-1. Bioessays, 25, 691-698.

Kojic S, Medeot E, Guccione E et al. 2004. The Ankrd2 protein, a link between the sarcomere and the nucleus in skeletal muscle. J Mol Biol, 339, 313-325.

Kuwano M, Toh S, Uchiumi T, Takano H, Kohno K and Wada M. 1999. Multidrug resistance-associated protein subfamily transporters and drug resistance. Anticancer Drug Res, 14, 123-131.
Kuwano M, Uchiumi T, Hayakawa $\mathrm{H}$ et al. 2003. The basic and clinical implications of $\mathrm{ABC}$ transporters, Y-box-binding protein-1 (YB-1) and angiogenesis-related factors in human malignancies. Cancer Sci, 94, 9-14.

Levenson VV, Davidovich IA and Roninson IB. 2000. Pleotropic resistance to DNA-interactive drugs is associated with increased expression of genes involved in DNA replication, repair and stress response. Cancer Res, 60, 5027-5030.

Lu ZH, Books JT and Ley TJ. 2005. YB-1 is important for latestage embryonic development, optimal cellular stress responses, and the prevention of premature senescence. Mol Cell Biol, 25, 4625-4637.

Matsumoto K and Wolffe AP. 1998. Gene regulation by Y-box proteins: coupling control of transcription and translation. Trends Cell Biol, 8, 318-323.

Matsumoto K, Tanaka KJ and Tsujimoto M. 2005. An acidic protein, YBAP1, mediates the release of YB-1 from mRNA and relieves the translational repression activity of YB-1. Mol Cell Biol, 25, 1779-1792.

Michalides R, van Tinteren H, Balkenende A et al. 2002. Cyclin $\mathrm{A}$ is a prognostic indicator in early stage breast cancer with and without tamoxifen treatment. Br J Cancer, 86, 402-408.

Moorthamer M, Zumstein-Mecker S and Chaudhuri B. 1999. DNA binding protein dbpA binds Cdk5 and inhibits its activity. FEBS Lett, 446, 343-350.

Moraes KC, Quaresma AJ, Maehnss K and Kobarg J. 2003. Identification and characterization of proteins that selectively interact with isoforms of the mRNA binding protein AUF1 (hnRNP D). Biol Chem, 384, 25-37.

Oda Y, Sakamoto A, Shinohara N et al. 1998. Nuclear expression of YB-1 protein correlates with P-glycoprotein expression in human osteosarcoma. Clin Cancer Res, 4, 2273-2277.

Oda Y, Ohishi Y, Saito T, et al. 2003. Nuclear expression of Ybox-binding protein-1 correlates with P-glycoprotein and topoisomerase II alpha expression, and with poor prognosis in synovial sarcoma. J Pathol, 199, 251-258.

Ohga T, Koike K, Ono M et al. 1996. Role of the human Y box-binding protein YB-1 in cellular sensitivity to the DNAdamaging agents cisplatin, mitomycin $\mathrm{C}$, and ultraviolet light. Cancer Res, 56, 4224-4228.

Okamoto T, Izumi H, Imamura T et al. 2000. Direct interaction of $\mathrm{p} 53$ with the Y-box binding protein, YB-1: a mechanism for regulation of human gene expression Oncogene, 19, 29552966.

Raffetseder U, Frye B, Rauen T et al. 2003. Splicing factor SRp30c interaction with Y-box protein-1 confers nuclear YB1 shuttling and alternative splice site selection. J Biol Chem, 278, 18241-18248.

Safak M, Gallia GL and Khalili K. 1999. Reciprocal interaction between two cellular proteins, Puralpha and YB-1, modulates transcriptional activity of JCVCY in glial cells. Mol Cell Biol, 19, 2712-2723.

Saji H, Toi M, Saji S, Koike M, Kohno K and Kuwano M. 2003. Nuclear expression of YB-1 protein correlates with Pglycoprotein expression in human breast carcinoma. Cancer Lett, 190, 191-197.

Shibahara K, Sugio K, Osaki T et al. 2001. Nuclear expression of the Y-box binding protein, YB-1, as a novel marker of disease progression in non-small cell lung cancer. Clin Cancer Res, 7, 3151-3155.

Shibahara K, Uchiumi T, Fukuda T et al. 2004. Targeted disruption of one allele of the Y-box binding protein-1 (YB-1) gene in mouse embryonic stem cells and increased sensitivity to cisplatin and mitomycin C. Cancer Sci, 95, 348-353.

Shibao K, Takano H, Nakayama Y et al. 1999. Enhanced coexpression of YB-1 and DNA topoisomerase II alpha genes in human colorectal carcinomas. Int J Cancer, 83, 732-737.

Shnyreva M, Schullery DS, Suzuki H, Higaki Y and Bomsztyk K. 2000. Interaction of two multifunctional proteins. Hetero- 
geneous nuclear ribonucleoprotein $\mathrm{K}$ and Y-box-binding protein. J Biol Chem, 275, 15498-15503.

Skabkina OV, Lyabin DN, Skabkin MA and Ovchinnikov LP. 2005. YB-1 autoregulates translation of its own mRNA at or prior to the step of $40 \mathrm{~S}$ ribosomal subunit joining. Mol Cell Biol, 25, 3317-3323.

Soop T, Nashchekin D, Zhao J et al. 2003. A p50-like Y-box protein with a putative translational role becomes associated with pre-mRNA concomitant with transcription. J Cell Sci, 116, 1493-1503.

Swamynathan SK, Nambiar A and Guntaka RV. 1998. Role of single-stranded DNA regions and Y-box proteins in transcriptional regulation of viral and cellular genes. FASEB J, 12, 515-522.

Swamynathan SK, Varma BR, Weber KT and Guntaka RV. 2002. Targeted disruption of one allele of the Y-box protein gene, Chk-YB-1b, in DT40 cells results in major defects in cell cycle. Biochem Biophys Res Commun, 296, 451-457.

Torigoe $\mathrm{T}$, Izumi $\mathrm{H}$, Ishiguchi $\mathrm{H}$ et al. 2005. Cisplatin resistance and transcription factors. Curr Med Chem Anti-Canc Agent, 5, 15-27.

Uramoto $\mathrm{H}$, Izumi $\mathrm{H}$, Ise $\mathrm{T}$ et al. 2002. p73 interacts with cMyc to regulate Y-box-binding protein-1 expression. J Biol Chem, 277, 31694-31702.

Wilhelm JE, Mansfield J, Hom-Booher N et al. 2000. Isolation of a ribonucleoprotein complex involved in mRNA localization in Drosophila oocytes. J Cell Biol, 148, 427-440.

Wilkinson MF and Shyu AB. 2001. Multifunctional regulatory proteins that control gene expression in both the nucleus and the cytoplasm. Bioessays, 23, 775-787.

Yahata H, Kobayashi H, Kamura T et al. 2002. Increased nuclear localization of transcription factor YB-1 in acquired cisplatin-resistant ovarian cancer. J Cancer Res Clin Oncol, 128, 621-626.

Yang J, Medvedev S, Reddi PP, Schultz RM and Hecht NB. 2005a. The DNA/RNA-binding protein MSY2 marks specific transcripts for cytoplasmic storage in mouse male germ cells. Proc Natl Acad Sci U S A, 102, 1513-1518.

Yang J, Medvedev S, Yu J et al. 2005b. Absence of the DNA/RNA-binding protein MSY2 results in male and female infertility. Proc Natl Acad Sci U S A, 102, 5755-5760.

Zhang YF, Homer C, Edwards SJ et al. 2003. Nuclear localization of Y-box factor YB1 requires wild-type p53. Oncogene, 22, 2782-2794

Zimmer SG, DeBenedetti A and Graff JR. 2000. Translational control of malignancy: the mRNA cap-binding protein, eIF$4 \mathrm{E}$, as a central regulator of tumor formation, growth, invasion and metastasis. Anticancer Res., 20, 1343-1351.

Zou Y, Evans S, Chen J et al. 1997. CARP, a cardiac ankyrin repeat protein, is downstream in the Nkx2-5 homeobox gene pathway. Development, 124, 793-804.

\section{SHORT COPYRIGHT STATEMENT}

This is an open access article, published under the terms of the Licence for Users available at http://www.libpubmedia.co.uk/ MedJ/LicenceForUsers.pdf. This licence permits noncommercial use, distribution and reproduction of the article, provided the original work is appropriately acknowledged with correct citation details. 